Колесина К.Ю.

\title{
Принципы разработки интегративной компетентностно ориентированной программы проектной деятельности старшеклассников
}

В статье рассматривается значение, теоретические, процессуальные и организачионные основы разработки интегративной метапредметной программы проектной деятельности, ориентированной на формирование ключевых компетентностей учащихся. Основная характеристика образовательных проектов, входящих в программу - их компетентностное многообразие, возможность освоения в прочессе их реализачии различных типов ключевых компетентностей - коммуникативной, сочиальной, когнитивной, общекультурной.

Ключевые слова: компетентностное многообразие проектов, ключевые компетентности, метапредметная программа проектной деятельности, природосообразность, витагенность, комплексность, универсальность.

По мнению многих отечественных и зарубежных педагогов, технология проектного обучения все больше выдвигается в ведущие дидактические средства современного образования. Метод проектов называют «методом, разрушающим школьную рутину» /М. Эпштейн/; попыткой избавить учителя от обязанностей всезнающего оракула» М.Чечель/; технологией, «направленной на раскрытие смысловой основы мира» М. Абакумова/; «универсальной технологией с позиций компетентностного подхода» /Н.Ю.Пахомова/.Однако, несмотря на активно формирующийся в российской системе образования опыт проектного обучения, многие ученые-педагоги /Н.Ю. Пахомова, Т.И. Шамова и др./ считают нецелесообразным переводить весь образовательный процесс на проектное обучение. Более перспективным в настоящее время считается создание надпредметных образовательных программ, учитывающих особенности конкретного учреждения образования, социальной среды, состава учащихся, потенциала педагогических кадров. Учитывая задачи формирования ключевых компетентностей учащихся, поставленные перед современной школой, мы предлагаем программу интегративной метапредметной деятельности, которая по своему содержанию не просто выходит за рамки какого-либо учебного предмета и даже образовательной области - она интегрирует в себе информацию из самых разнообразных сфер знаний, требует их конструирования на другом уровне - метауровне, содержание которого существенно превышает содержание учебных программ, хотя на общекультурном, доступном для старшеклассника уровне.

«Мета» в переводе с греческого означает «после», «за», «через». Образовательная метапредметная программа проектной деятельности учащихся, таким образом, находится «за» пределами школьных курсов; она открывает совершенно новые связи и отношения в объектах проектной деятельности, которые лишь в незначительной 
степени касаются базисного содержания образования. Метапредметная программа проектной деятельности учащихся, охватывая, с одной стороны, весь комплекс образовательных областей учебного плана профильного образования, с другой представляет собой комплект надпредметных проектов. Более того, каждый из интегративных проектов призван выполнять метаобразовательную задачу: создавать условия для освоения учащимися опыта компетентностной деятельности, причем в сфере ключевых компетенций - коммуникативной, социальной, когнитивной, общекультурной.

Исходные теоретические основы конструирования подобной программы определяются на основе ряда позиций, полностью соответствующих принципам компетентностного подхода к образованию, что дает основание назвать проектную деятельность старшеклассников компетентностно ориентированной, соответствующей принципам:

гуманистической педагогики, утверждающей самоценность ребенка как личности, необходимости развития его индивидуальности, нравственного самосознания, признание ценностно-смыслового равенства взрослого и ребенка;

- деятельностного подхода, согласно которому образовательный процесс строится не в соответствии с логикой учебного процесса, а адекватно логике познавательной деятельности, имеющей личностные смыслы для ученика;

- индивидуализации обучения, поскольку работа над проектом требует принятия субъективных смыслов, индивидуального темпа проектирования, рефлексии, самоконтроля; комплексности в разработке проектов, способствующей сбалансированному развитию не только проектируемых ключевых компетентностей, но и основных физиологических и психологических функций;

- универсальности, предполагающей освоение ключевых компетентностей за счет их универсальной реализации в различных видах проектной деятельности;

- сотрудничества педагогов и учащихся в работе над интегративным проектом, организации совместной компетентностной деятельности;

- природосообразности, ориентирующей на организацию проектной деятельности, соответствующей интересам, возрастным особенностям и личностным предпочтениям ученика и использование окружающей среды как лаборатории, в которой осуществляется процесс познания;

- $\quad$ витагенности, предполагающей актуализацию жизненного опыта ученика и степень развития его ключевых компетентностей, ориентацию на его интеллектуально-личностный потенциал.

Компетентностное многообразие - важнейшая черта каждого метапредметного проекта, составляющего программу интегративной проектной деятельности старшеклассников.

Процессуальной основой организации метапредметной проектной деятельности учащихся является:

- реализация в процессе работы над проектом личностного образовательного потенциала старшеклассника;

получение субъективно и, возможно, объективно значимого результата проектной деятельности;

- наращивание активно приобретенного опыта компетентностной деятельности;

- освоение опыта коллективно познавательной деятельности, достижение коллективно полученных результатов;

- выстраивание индивидуальных траекторий проектно-компетентностной деятельности;

- самоконтроль, самокоррекция, самооценка, поэтапная рефлексия проектной деятельности; 
- $\quad$ направленность каждого проекта на практическое освоение ключевых компетентностей и усвоение системы обеспечивающих их знаний;

- учет личностных предпочтений старшеклассников, изучение и учет субъективных возможностей, уровня развития познавательной мотивации, интеллектуальных способностей, исходного уровня развития ключевых компетентностей, направления профильной подготовки и др.;

- анализ средств /информационных, технических, экспериментальных/, необходимых для выполнения конкретно каждого проекта, в том числе и доступа к компьютерным носителям информации;

- степень разработанности материалов, сопровождающих проектную деятельность учащихся / «Положения о проектной деятельности», Методического паспорта каждого проекта, утвержденного графика проектной деятельности старшеклассников, Протокола согласования с Учебным планом и школьным расписанием и т.д./.

Организационной основой реализации метапредметной программы проектной деятельности старшеклассников является включение в Базисный план профильного обучения /БУП - 2004/ отдельного раздела организации практик, исследовательской и проектной деятельности учащихся 10-11-х классов /1-2 часа в неделю в зависимости от профиля/.

К условиям, обеспечивающим эффективность проектной деятельности, мы относим:

1. Детальную разработку всех этапов проектной деятельности учащихся - от «Введения в проект» до «Презентации результатов проектной деятельности», проектирование целей и прогнозирование результатов проектирования - как по этапам, так и по окончанию работы над проектом.

2. Обучение учащихся технологии метапредметной проектной деятельности, оказание им педагогической поддержки на каждом этапе проектирования, активное вовлечение школьников в обсуждение проекта на основе «погружения» в его проблематику.

3. Актуализация и самоактуализация смысловой сферы личности, мотивационное сопровождение проекта на всех этапах его выполнения.

4. Учет уровня информированности учащихся по тематике проекта, доступности информационных средств проектирования, экспериментальной базы, возможностей получения консультативной помощи.

5. Владение педагогами - руководителями проектов технологией проектной деятельности, необходимым уровнем компетентности в области проблем, положенных в основу разрабатываемого проекта, интерес и готовность к работе по проектной образовательной технологии.

6. Понимание учителем «сверхзадачи» организации метапредметной проектной деятельности старшеклассников - обеспечение условий для освоения ими опыта компетентностной деятельности, развития ключевых компетентностей обучающихся.

\section{Литература:}

1. Абакумова И.В. Обучение и смыслообразование в учебном процессе. Ростов-наДону. 2003.

2. Пахомова Н.Ю. Что такое метод проектов?// Школьные технологии. 2004. № 4.

3. Чечель И. Метод проектов или попытка избавить учителя от обязанностей всезнающего оракула // Директор школы. 1998. № 3.

4. Эпштейн М. Метод, разрушающий школьную рутину (о методе проектов) // Педагогическая техника. 2004. № 2. 